\title{
The six dimensions of collective leadership that advance sustainability objectives: rethinking what it means to be an academic leader
}

\author{
$\underline{\text { Jill Caviglia-Harris }}^{1}, \underline{\text { Karen E. Hodges }}^{2}, \underline{\text { Brian Helmuth }}^{3}, \underline{\text { Elena M. Bennett }}^{4}, \underline{\text { Kathleen Galvin }}^{5}$ Margaret Krebs $^{6,7}, \underline{\text { Karen Lips }}^{8}$,

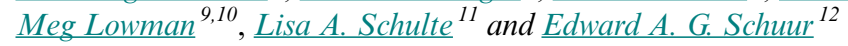

\begin{abstract}
Solutions to our most pressing environmental problems demand the development and application of leadership skills that are not typically fostered in traditional academic programs: skills that advance new transdisciplinary approaches to co-produce knowledge that can be mobilized for action. We outline a new collective leadership model with six dimensions, Inquire, Connect, Engage, Strategize, Empower, and Reflect, and show through a series of case studies how each of these leadership dimensions can be used to create positive and lasting change for people and their environments. We also describe how academic researchers can learn to apply these dimensions in their own work and introduce a series of companion online narratives and teaching resources designed to facilitate the use of this collective leadership model in classrooms.
\end{abstract}

Key Words: collective leadership; knowledge to action; sustainability; transdisciplinary leadership

\section{INTRODUCTION}

Most pressing environmental problems are complex, cross jurisdictional borders, and require a mix of scientific, stakeholder, and transdisciplinary knowledge to be addressed effectively (Safford et al. 2017). Although it is widely known that using scientific, practical, and experiential knowledge to inform policy, grassroots, and other action is key to addressing such issues (van Kerkhoff and Lebel 2006, Muñoz-Erickson and Cutts 2016), many questions remain about how to bridge the gap between knowledge and action. Policy makers seldom read academic journals (Dilling and Lemos 2011, Clark et al. 2016), practitioners rarely work with academics, and researchers often do not translate findings to other media (Brownell et al. 2013). The "science of science communication" focuses on learning how to improve communication of key scientific knowledge (Fischhoff and Scheufele 2013, 2019), but this translation is not enough if we are to continue to improve our efforts toward leadership (Fischhoff 2019). Knowledge-based action requires approaches that link the scientific, stakeholder, and policy worlds (van Kerkhoff and Lebel 2006, Matson et al. 2016) when addressing this "researchimplementation gap" (Lauber et al. 2011). This gap is particularly evident in academic research cultures (APLU 2019, NASEM 2020), where tenure and promotion guidelines prioritize recognition by academic peers and publications in scientific journals, rather than efforts to co-produce (Ostrom 1996) and mobilize (Fazey et al. 2013) knowledge that directly informs and guides societal action.

Here we build on what Clark et al. (2016) refer to as "capacities to mobilize knowledge," and define action as initiatives that mobilize knowledge to increase stakeholder engagement (through facilitation, citizen science activities, or other information- gathering efforts), social learning (through changes in health outcomes, quality of life, beliefs, attitudes, and behaviors), researcher training (through leadership initiatives and workshops on collective leadership), and knowledge governance (through changes in policy and law). Early approaches for addressing the research-implementation gap focused on providing researcher knowledge to policy actors who would theoretically translate knowledge into action without any further input required by the researcher. These "loading dock" models of scientific knowledge dissemination (Cash et al. 2006) were based on the deficit model or the belief that simply delivering objective knowledge to the right stakeholders would lead to behavioral change and create “action" (Logan 2001, Bauer et al. 2007, Dudo and Besley 2016). In other words, the needs and perceptions of stakeholders would have no influence over how the information was collected or generated by the scientists.

In contrast, complexity-oriented approaches focus on the codevelopment of knowledge, ideas, and solutions by acknowledging that effective solutions to intractable problems must account for the diverse needs, priorities, experiences, and worldviews of multiple participants (Knapp et al. 2019, Stephens 2020). Complexity-oriented models suggest that researchers, stakeholders, and policy-makers should be involved in creating knowledge and translating it into action (West et al. 2019). Even though this approach is a tall order for researchers who are not trained in implementation strategies, it can play an important role in addressing sustainability issues. Teams composed of individuals from diverse disciplines (inside and outside of academia) who work toward a common goal, but often with very different approaches and thought processes, are frequently cited as the foundation of effective knowledge-to-action plans

\footnotetext{
${ }^{1}$ Economics and Finance Department, Environmental Studies Department, Salisbury University, ${ }^{2}$ Department of Biology, University of British Columbia Okanagan, ${ }^{3}$ Department of Marine and Environmental Sciences and School of Public Policy and Urban Affairs, Northeastern University, ${ }^{4}$ Department of Natural Resource Sciences and Bieler School of Environment, McGill University, ${ }^{5}$ Department of Anthropology and Geography, Colorado State University, ${ }^{6}$ Earth Leadership Program, ${ }^{7}$ Stanford Woods Institute for the Environment, Stanford University, ${ }^{8}$ Department of Biology, University of Maryland, College Park, ${ }^{9}$ TREE Foundation, ${ }^{10}$ National Geographic Explorer, ${ }^{11}$ Department of Natural Resource Ecology and Management and Bioeconomy Institute, Iowa State University, ${ }^{12}$ Center for Ecosystem Science and Society and Department of Biological Sciences, Northern Arizona University
} 
(Cockburn et al. 2016). The efficacy of such teams depends critically on how teams are led and whether the expertise and energy of all participants are acknowledged, respected, and wellused.

Leadership style can significantly impact team creativity (Gumusluoglu and Ilsev 2009), team performance, and a range of other important outcomes (Bass et al. 2003). Research suggests that transformational leadership (characterized by a leader with a communicated vision that appeals to higher ideals or moral values) is needed to advance solutions to complex problems (Bass 1985). Transformational leaders communicate their visions, expectations, and goals to elevate the interests of their team (Hamstra et al. 2014) by promoting collective commitment, e.g., through the use of "we" rather than "I," and reinforcing shared values (Haidt 2012). Collective leadership models build on these ideals by emphasizing emotional intelligence, humility, and reflection (Manolis et al. 2009) and by focusing on different sets of knowledge, perspectives, and skills than those needed for research alone (Gordon et al. 2019). Some early collaborative initiatives failed to meet their action objectives specifically because they did not incorporate collective leadership (Kristjanson et al. 2009, Senge et al. 2015) and did not include leaders who embraced approaches that focused on a nonhierarchical relationship among members (Senge et al. 2015).

Researchers, government officials, and stakeholders have responded to the need to address global environmental issues by creating collaborative initiatives and funding opportunities to bridge the knowledge-to-action gap (Miller 2013). For example, the U.S. National Climate Assessment now includes engagement among academics and stakeholders from industry and civil society to facilitate the implementation, distribution, and synthesis of climate adaptation strategies (NASEM 2017). Funding agencies, recognizing the critical role of addressing environmental problems within the context of a coupled natural and human system (Baerwald et al. 2016), have likewise initiated programs to support collaborations between academic and nonacademic partners. For example, the U.S. NOAA National Sea Grant Program integrates engagement with cutting edge research to tackle problems facing coastal communities (Miloy and Crowder 1983); the U.S. National Science Foundation's Convergence Accelerator program (https://www.nsf.gov/od/oia/ convergence-accelerator/) brings together partners from academia, industry, government, and non-governmental organizations; and the NSF Coastlines and People program (Teutonico et al. 2020) has, as a guiding principle, the necessity of forging lasting connections between scientists/engineers and coastal communities. In Canada, the New Frontiers in Research Fund supports "interdisciplinary, international, high-risk/highreward, transformative and rapid-response Canadian research" (https://www.sshrc-crsh.gc.ca/funding-financement/nfrf-fnfr/indexeng.aspx). Finally, many initiatives of the European Union's Horizon 2020 Programme for Research and Innovation explicitly connect academic and non-academic partners (https://ec.europa. eu/programmes/horizon2020/en).

In this paper, we outline a collective leadership model that builds on leadership research, knowledge-to-action models, and other efforts to advance sustainability initiatives. We highlight six dimensions of leadership - Inquire, Connect, Engage, Strategize,
Empower, and Reflect - with case studies from which researchers can draw. We further introduce a set of teaching resources that demonstrate these principles in action. This approach has led to research findings incorporated in the United States Farm Bill, calling out policy suggestions in a U.S. Presidential address, and increased efforts to monitor and restore biodiversity in war-torn Iraq. In the cases we provide, none of this integration of evidence into action happened passively or because policy makers read the academic literature; rather it required training, deliberate planning, and inclusive approaches for engaging teams.

\section{THE COLLECTIVE LEADERSHIP DIMENSIONS}

Academic researchers who dedicate their lives to studying sustainability have an authoritative understanding of their science and know how to succeed in academia (Miller 2013). However, translating knowledge into lasting societal change is challenging (Matson et al. 2016) and requires the difficult task of ensuring that knowledge is aspirational, applicable, and co-produced (Francis et al. 2018). Interactions with boundary organizations (entities that facilitate collaboration and information flow between different communities) can play an important role in translating knowledge between stakeholders and researchers (Guston 2001, Safford et al. 2017), but public participation, integration with the public's needs, and power sharing can also be important for researchers to engage in if knowledge-to-action initiatives are to succeed (van Kerkhoff and Lebel 2006). The proficiencies required for scholars to make these links between scientific knowledge and the public arena are rarely taught in graduate school (Gray 2008, NASEM 2018), but they can serve as a critical tool for putting academic knowledge into action, and, as exemplified here, can open new opportunities for academic research.

Collective leadership focuses on developing the co-production relationships that allow for the knowledge and decision-making processes to shape one another (Clark et al. 2016). This approach does not necessarily eliminate the role of the focal leader, but does allow for leadership to shift according to expertise and task, and move between team members as the collectivistic process changes (Denis et al. 2001, Friedrich et al. 2016). Collective leadership approaches enhance team performance (Mendez et al. 2015), improve participant engagement (McAuliffe et al. 2017), and assist in the development of solutions to real world problems (Ward et al. 2018). Transdisciplinary leadership, on the other hand, refers to leadership that builds the co-production process using different disciplinary actors within academia and stakeholders outside of academia (Gray 2008). The transdisciplinary approach includes matching the current needs of society to research questions, identifying the relevant disciplines and societal actors to address problems, and reflecting on the process (Pohl et al. 2017). Thus, there is overlap between collective and transdisciplinary leadership.

Our collective leadership model focuses on developing the relationships needed to mobilize knowledge that is salient, credible, and legitimate for action (Cash et al. 2003, Gerber et al. 2020) and builds on leadership research, knowledge-to-action models, and other efforts to advance sustainability initiatives that underpin the Earth Leadership Program (ELP). The ELP ${ }^{[1]}$ was founded in 1998 as the Leopold Leadership Program (LLP) to train environmental scientists to become effective at integrating 
their scientific knowledge and expertise into strategies for communication to diverse stakeholders (Lubchenco 1998). The first workshops were convened under the auspices of the Ecological Society of America. In 2003 the program moved to the New England Aquarium, and in 2005 to Stanford University. A 2008 program evaluation shifted emphasis from communicating science to mobilizing knowledge for action. Motivated by calls to move past the deficit model and respond to the parallel development of sustainability science (Clark 2007, Clark and Harley 2020, Fazey et al. 2020), the foci of the program became (1) the co-production of knowledge with transdisciplinary teams (including members within and outside of academia) and (2) capacity development (Clark et al. 2016).

The LLP is now recognized as one of the first organizations to train faculty researchers to be "change agents" (Kapitulčinová et al. 2018) and has been reorganized and rebranded to engage at the global scale as the Earth Leadership Program (co-sponsored by Future Earth, Stanford Woods Institute for the Environment and the University of Colorado, Boulder). Fellows work with the private sector, government agencies (national and international), educators, farmers, ranchers, industry, resource managers, and boundary organizations. The trial and error experiences of the fellows provide the guidelines, narratives, and case studies on how to mobilize knowledge for action. The Inquire, Connect, Engage, Strategize, Reflect, and Empower dimensions of collective leadership emerged over the past decade as practitioners and thought leaders assessed the need for a new leadership model for situations that are complex and multifaceted and where solutions are likely to be iterative. In the model outlined in Figure 1, the six dimensions form a circle without a particular starting point, suggesting that leaders can begin with any one of these dimensions. The lines between the dimensions show iteration and suggest that leaders can move between these dimensions in different orders. For example, being reflective and evaluating positive and negative progress toward goals is an important capacity for sustainability scientists (Matson et al. 2016) and is likely needed to advance many of the other dimensions.

Fig. 1. The collective leadership model. The six dimensions of this framework outline how sustainability leaders build trust, work with stakeholders to co-produce usable knowledge, and make lasting positive change.

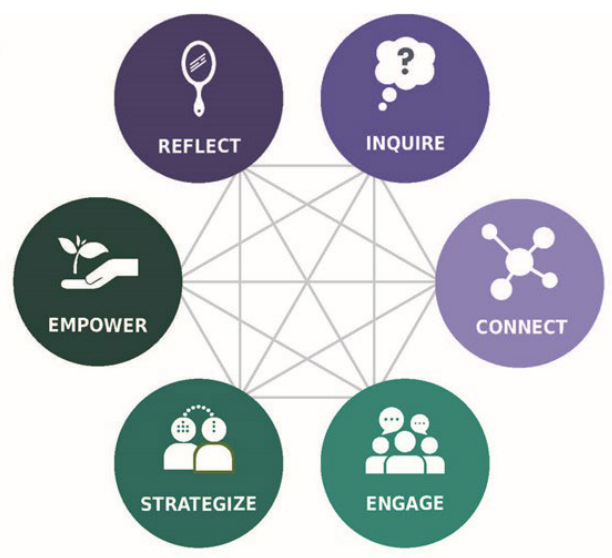

This collective leadership model sees leadership as a collaborative process that considers the diverse opinions, values, and experiences of all team members as opposed to a position held by a single individual. The traits valued include intentionality, learning, empathy, and systems thinking, rather than fixation on a single dominant narrative. The model is intended to deconstruct the frequently cited terms co-design and co-production using leadership attributes so as to translate the process into actionoriented verbs (Reflect, Inquire, Connect, Engage, Strategize, Empower). Given that the capacities needed to facilitate effective transdisciplinary research are well-documented and reviewed, we relied on that research to inform the model. For example, to dialog with decision makers, leaders must "inquire." Our intention is to capture the capacity or practice of asking powerful questions to gain insights from multiple perspectives (Moser 2016). Our approach recognizes that problem-solving and innovation are much more likely when the collective experiences of people with disparate world views are valued and that knowledge is more likely to be created from a two-way dialog between experts and decision makers rather than from one-way efforts in science communication. In this frame, the collective leader convenes a group to create a shared vision, instead of creating and then sharing a single vision to the larger group; and they grow with self-awareness by reflecting on successes and failures, instead of only deepening knowledge within the boundaries of their expertise. Finally, collective leaders increase engagement and likelihood of success and implementation by transforming systems, creating changes toward a sustainable future, and acting from a networked mindset. One of the most important principles in this leadership model is the development of the long-term relationships that are key for transforming knowledge into action (Généreux et al. 2019).

The following sections outline each of the six dimensions of the Collective Leadership Model (CLM) and provide examples and case studies for how these dimensions have been used to advance sustainability initiatives by program fellows. Information on detailed narratives and teaching tools for these and other CLM applications can be found in Table 1, which includes online references. Although the case studies that follow draw from larger and funded projects, these dimensions can be applied to any leadership position: from teaching, to co-authoring, to running a research lab.

\section{Inquire: gaining multiple perspectives}

To inquire is to gather multiple perspectives by asking questions, listening to answers, and learning to be empathetic to the viewpoints, knowledge, and ideas of others. As part of this process, researchers need to identify key stakeholders, seek out diverse perspectives, and reframe the challenge as needed. The work that Kathleen Galvin (Colorado State University) has undertaken with Kenyan herders highlights how this dimension can be used to address one of the negative impacts of regional climate change: the declining condition of livestock (Naess 2013). After working with these pastoral communities for decades, Galvin noted the negative impacts of reduced rainfall and more frequent droughts on livestock and used the relationships and partnerships she developed to host workshops with Kenyan and U.S. scientists and Kenyan herders in 2011 to gather input on the herders' first-hand experiences with changes to income opportunities and food production. This work built on prior 
Table 1. Narrative examples with corresponding online teaching tools.

\begin{tabular}{|c|c|}
\hline Narrative Summary & $\begin{array}{l}\text { Leadership } \\
\text { Dimensions }\end{array}$ \\
\hline Enabling Long-Term Planning in the Montérégie Region of Quebec: & Engage \\
\hline $\begin{array}{l}\text { Elena Bennett worked with a nature conservation group to plan and support future decision making for the Montérégie Connection, } \\
\text { an agricultural area near Montreal that is undergoing } \\
\text { a shift toward development (Mitchell et al. 2015). }\end{array}$ & $\begin{array}{l}\text { Strategize } \\
\text { Connect }\end{array}$ \\
\hline Leadership by Design: Reflections on Building an Interdisciplinary, Cross-Cultural, Action-Oriented Research Team: & Connect \\
\hline $\begin{array}{l}\text { Jill Caviglia-Harris led a working group to investigate the impacts of forest cover change on hydrological services in the Brazilian } \\
\text { Amazon. }\end{array}$ & Engage \\
\hline A Researcher’s Ethical Journey: From Traditional Science to Transdisciplinary Collaboration: & Reflect \\
\hline $\begin{array}{l}\text { Kathy Galvin describes her development as a researcher as she shifted her approach toward participatory, co-constructed knowledge } \\
\text { with Kenyan pastoralists grappling with impacts of environmental change on their way of life. }\end{array}$ & Inquire \\
\hline Lessons from Eden: & Reflect \\
\hline $\begin{array}{l}\text { Brian Helmuth developed an egalitarian partnership with Iraqi scientists seeking to restore } \\
\text { the Hammar Marshes and reestablish connections between the Iraqi and international scientific communities. }\end{array}$ & Connect \\
\hline It takes Three Beers: & Connect \\
\hline Karen Hodges created a new graduate program that includes training in knowledge-to-action by investing time into program & Reflect \\
\hline development and the social network needed to support the ideas of the program. & Strategize \\
\hline Stopping a Wildlife Disease from Becoming a Crisis: A Collaborative Leadership Success Story: & Strategize \\
\hline Karen Lips used her network of herpetologists, students, wildlife policy experts, and & Inquire \\
\hline journalists to lay the groundwork for an interim ban on the importation of salamanders to the U.S. & Engage \\
\hline Saving the Forests of Ethiopia, One Church at a Time: & Empower \\
\hline $\begin{array}{l}\text { Meg Lowman describes her work with priests at Coptic churches to support forest } \\
\text { conservation in northern Ethiopia and reflects on pathways for scaling her efforts to save "church forests." }\end{array}$ & Strategize \\
\hline Reflection, Empowerment, and Co-constructed Research: Leadership Lessons from an & Engage \\
\hline Initiative to Transform Iowa Agriculture: & Inquire \\
\hline $\begin{array}{l}\text { Lisa Schulte Moore and the STRIPS team built long-term, trusting relationships with farmers, farmland owners, agribusinesses, } \\
\text { government agencies, and NGOs to test new methods for conserving soil and reducing agricultural runoff into streams and rivers } \\
\text { flowing from Iowa into the Mississippi Basin. }\end{array}$ & Empower \\
\hline $\begin{array}{l}\text { Permafrost in a Changing Arctic: Developing a Human Network for Science, Communication, } \\
\text { and Action: }\end{array}$ & $\begin{array}{l}\text { Strategize } \\
\text { Connect }\end{array}$ \\
\hline $\begin{array}{l}\text { Ted Schuur examines the leadership training and tools that helped him to form the Permafrost Carbon Network aimed at science } \\
\text { synthesis and communication; and explains how this platform helped him engage with policy efforts aimed at managing a changing } \\
\text { climate. }\end{array}$ & Engage \\
\hline Holding My Own: A Story of Conflict, Collaboration, and Reef Conservation in Indonesia: & Reflect \\
\hline $\begin{array}{l}\text { Susan Williams related her story of navigating relationships with the university community in Indonesia, the Mars Foundation, and } \\
\text { the coral reef science community to make a breakthrough in coral reef rehabilitation that benefits biodiversity and the local } \\
\text { Indonesian economy. }\end{array}$ & Empower \\
\hline
\end{tabular}

research that showed that despite livelihood diversification under climate change, these populations remained poor and food insecure because of reduced livestock productivity, increased soil erosion, loss of water sources, lowering of the water table, and loss of mobility (Galvin et al. 2015).

The workshops drew pastoralists from across the country to examine how changes in the climate, environment, and livelihoods interact to shape community well-being and to address how local peoples are working to adapt to these changes (Galvin et al. 2020). The intent of these workshops was to gather the diverse perspectives, outline desired futures, and co-develop the actions needed to attain envisioned outcomes. These summaries revealed that the pastoralists and scientists both had (some different) evidence of serious change. Although the scientists had a good understanding of climate change and a general sense of its impacts on livelihoods, pastoralists demonstrated the variability of the relative importance of impacts depending on the region. For example, water scarcity and the potential for conflict were more important drivers of livelihood change in the north of the country than in other regions, and vegetation change and livestock disease were the most important drivers of livelihood change in the south. With this information, participants worked together to imagine a new future and outline the actions needed to achieve it (Galvin et al. 2020).

As a result of the workshops, a grant was written and funded to bring herders from around the world to the U.S. to discuss climate change and how it affected their homelands (Galvin et al. 2016). A series of videos was also produced. These videos demonstrated the environmental changes occurring in the Kenyan drylands, then outlined pathways for policy and cultural change at multiple levels of governance to address economic well-being among communities who depend upon natural resources to sustain their livelihoods. These videos have been used in social science classrooms at Colorado State University and at international venues on global climate change (Pastoralist Voices on Climate Change 2011; Maasai Voices on Climate Change: A Participatory Video 2012). And, some of the workshop attendees are now advocating for policy changes via the Kenyan Wildlife Conservancies Association (https://kwcakenya.com/). 


\section{Connect: act from a networked stance}

To connect, researchers must understand the social and historical contexts within which the issue of focus is occurring, as well as the social networks and stakeholders that are relevant to the issue at hand. Through conversation and dialogue, a researcher can frame the issue and the context by identifying the cross-sector and cross-disciplinary stakeholders and allies and any roadblocks that may have prevented success in the past. A key component for making these connections is to recognize one's own assumptions and biases, particularly when working in foreign or multicultural environments, and especially in areas of recent or ongoing conflict (Hanson 2018). The experiences of Brian Helmuth (Northeastern University) in southern Iraq provide such an example. Beginning in 2012, at the invitation of the University of Basrah, Helmuth traveled to Iraq to forge collaborations with their faculty, and to explore methods for monitoring and restoring biodiversity and ecosystem function in the Mesopotamian marshlands, Shatt AlArab river, and northern Arabian (Persian) Gulf (Richardson et al. 2005). Through a series of attempts to initiate a training and research program, which repeatedly stalled because of repeated outbreaks of civil unrest primarily associated with the rise of the Islamic State (Bunzel 2015), Helmuth developed close ties and friendships with his Iraqi colleagues, Drs. Malik Hasan Ali, Nadia Al-Mudaffar Fawzi, and Ali Douabul. Somewhat ironically, the political unrest and resulting delays created additional time for the team members from two very different cultures to connect with each other, learn from each other, and establish strong working relationships. It also offered a chance for Helmuth to better understand the history of the region and the context for why collaborative relationships had frequently stalled in the past. Specifically, the myth of the "western environmental savior," i.e., the "hero narrative" (Flaherty 2016), had created lasting damage and needed to be acknowledged (with this collaborative approach that respected the needs, skills, and experiences of all partners) before true progress could be made.

Since the onset of the Iran-Iraq war in 1980, the nation of Iraq has been in near constant political turmoil with subsequent severe ecological damage, especially to the Mesopotamian marshlands in southeastern Iraq (Al-Mudaffar Fawzi and Mahdi 2014). Once the largest wetlands in the Middle East (UNEP 2001), and considered by many scholars to be the "cradle of civilization," these marshes are home to an indigenous population, the Marsh Arabs, who for millennia have relied on the ecosystem services provided by the wetlands (Thesiger 1964, Al-Mudaffar Fawzi et al. 2016). Today upwards of $90 \%$ of the green biomass in the marsh has disappeared (Albarakat et al. 2018) largely as a result of the deliberate destruction of the marshes by Saddam Hussein's Ba'ath regime in the 1990s (UNEP 2001) but exacerbated more recently by climate change and river damming (Al-Mudaffar Fawzi and Mahdi 2014). Brief windows of opportunity occurred during respites in the social unrest, allowing western NGOs opportunities to offer assistance. Discussions among team members and their colleagues revealed that while some research programs had been highly effective (e.g., Al-Mudaffar Fawzi et al. 2016), other international programs had failed to incorporate or even acknowledge the extensive expertise provided by Iraqi scientists, and that some Iraqi scientists had felt disenfranchised and paternalized. By discussing the perceptions of their peers, the Iraqi-American team was able to facilitate a deeper understanding of how prior failures of some western scientists and NGO workers to authentically engage Iraqi scientists had influenced Iraqi perceptions and expectations of western academics. Conversely, it also pointed to biased or uninformed perceptions of Iraqis among many Americans.

With the support of the U.S. Department of State and the Partnerships for Enhanced Engagement in Research (PEER) program, administered by USAID and the U.S. National Academies of Science, Helmuth, Ali, Al-Mudaffar Fawzi, and Douabul, working with the assistance of the non-profit organization "Nature Iraq," were eventually able to initiate a research program to document the impacts of civil conflict and environmental change on biodiversity in the region. The team also launched a training program that included the exchange of students and faculty between the U.S. and Iraq in 2018. The group engaged with high level officials within the Iraqi government to facilitate a better understanding of the importance of ecosystem services and discuss strategies for their restoration. A key to the success of this program was open and honest communication about the expectations and needs of all team members, and a recognition of past mistakes. At the time of this writing, the political and socioeconomic situation in Iraq remains extremely challenging and security considerations have put most of the project on hold, but the groundwork has now been laid for rapid resumption of collaborative efforts when the next window of opportunity opens.

\section{Engage: co-design, co-produce, and co-implement with stakeholders}

Engagement among researchers, stakeholders, and policy makers is needed to create shared goals and ensure a direction for the group when multiple non-academic parties are required to generate knowledge or solutions (Hurlbert and Gupta 2015). Engagement means more than connecting interested parties: it requires that longer term relationships and a shared vision are developed. This cohesion occurs when parties are brought together to co-produce knowledge, co-develop a mission, and codesign the action pieces (Ansell and Gash 2008). To engage effectively, a researcher can convene multi-stakeholder groups, assess potential opportunities and interventions, and develop shared work plans. These efforts and the identification of group goals are important because they lay the foundation needed for teams to work cohesively and be able to seize opportunities when they arise.

The STRIPS (Science-based Trials of Rowcrops Integrated with Prairie Strips, https://www.nrem.iastate.edu/research/STRIPS/ project, co-led by Lisa Schulte Moore (Iowa State University), is an example of how engagement can lead to practical solutions to sustainability issues. In this case, an interdisciplinary team of scientists, extension specialists, and practitioners assembled to solve some of the most pressing environmental challenges associated with U.S. Corn Belt agriculture in the mid-2000s. The team initially engaged farmers, farmland owners, agribusinesses, government agencies, and NGOs through in-depth interviews (Atwell et al. 2009), annual stakeholder meetings, presentations, and extension publications (Schulte et al. 2008, STRIPS 2017a, $\mathrm{b}, \mathrm{c}, \mathrm{d}, \mathrm{e})$. The resulting conservation practice - prairie stripsproved highly effective in experimental settings (Schulte et al. 2017), and generated interest from farmers. With funding from 
multiple units within the U.S. Department of Agriculture, the team worked with farmers to place prairie strips on commercial farms beginning in 2012. Crucial to this process was the recognition of farmers as professionals and as the experts on their farms. Designs for prairie strips on commercial farms were coproduced, with several iterations of information flow before farmers determined the best design for their farm and implemented them. The team provides farmer cooperators with annual reports detailing the data collected on their farms, and administers an annual survey to solicit farmer knowledge and feedback. Between 2012 and 2018, the team partnered with farmer cooperators to deliver 285 presentations and 63 field days, which reached 11,155 people; prairie strips were also featured in 168 news articles. This community engagement paired science results with farmer testimonials, and led to prairie strips being considered an acceptable conservation practice among a representative sample of Iowa farmers by 2018 (Arbuckle 2019a, b).

In late 2018, prairie strips became eligible for federal Conservation Reserve Program (CRP) funding with the U.S. Agricultural Improvement Act (a.k.a. "The Farm Bill”; U.S. Congress 2018), evidence that efforts to combine science with community engagement and investment in relationships can pay off. Farmers can now receive CRP funding for prairie strip installation. CRP is the largest private land conservation program in the U.S., providing approximately $\$ 2$ billion annually to directly fund conservation on up to 27 million acres (USDA FSA 2019). USDA expects widespread use of prairie strips in areas where there is potential for water quality and wildlife benefits (Mayer 2020).

\section{Strategize: be credible, relevant, and legitimate}

Strategizing is the development of calculated solutions that are co-produced and co-implemented with partners to encourage change. Successful implementation requires the alignment of multiple independent lines of effort from different partners. Getting the timing right for action can therefore be key. This dimension requires leaders to identify roles and responsibilities, communicate plans, and interact with partners on a continual basis. The founding of the Permafrost Carbon Network by Ted Schuur (Northern Arizona University) and colleagues Dave McGuire and Christina Schaedel, and its role in 2015 White House climate policy, provides such an example.

The Permafrost Carbon Network (PCN) was founded in 2011 to create new knowledge about climate change through science synthesis. The main objective of the network was to distill the findings of the primary literature into synthesis publications: to take the findings from individual research publications and create technical and conceptual synthesis papers that could then be used to create less technical summaries (and eventually two-page briefings) to answer key societal questions in language accessible to those in the policy world. These non-technical summaries and briefings were fundamental to Schuur's strategy to develop contacts at the U.S. Department of Energy. To make these contacts, he scheduled meetings with U.S. Senate and House staffers, participated in the Climate Science communication day on the Hill and the Arctic Alerts briefing, and gave webinar presentations to decision-maker groups such as the Interagency Arctic Research Policy Committee.

These strategic outreach efforts paid off. In the process, Schuur identified a champion for the Permafrost Carbon Network: Mike Kuperberg of the U.S. Department of Energy. It was a two-page brief from the Permafrost Carbon Network on permafrost and climate that was delivered by Kuperberg to the Obama administration that led President Obama to highlight the role of permafrost carbon in global environmental change and the need for action at the GLACIER conference in Anchorage, Alaska (Brigham 2015). At this conference, Obama described the feedback from carbon frozen in permafrost to climate change: As the Arctic warms, the permafrost thaws, the carbon in it starts to decompose, more greenhouse gases are released into the atmosphere, and climate change increases at a faster rate. President Obama used this argument to frame why we need action on climate change. Schuur's strategic networking groundwork was fundamental to making sure the work of the Permafrost Carbon Network was aligned with, and incorporated into, White House initiatives on climate change.

\section{Reflect: assess strengths, weaknesses, and values}

To reflect is to assess the strengths and weaknesses of the current approach. More specifically, the researcher evaluates personal strengths and weaknesses, reviews time commitments, and envisions team capabilities. The aim is to identify strengths and correct or compensate for weaknesses. The late Susan Williams (University of California, Davis), director of the Bodega Marine Laboratory in California, renowned coral reef scientist, and wellrespected mentor (Dennison et al. 2021), exemplified this leadership element through her work in Indonesia, where she collaborated with the candy manufacturing giant Mars, Inc. to restore damaged coral reefs. Mars was committed to engaging in sustainable cocoa practices in Indonesia and was eager to expand its efforts to build marine science infrastructure to restore the country's coral reefs in collaboration with scientists from Hasanuddin University. Williams intended to apply a major shift in thinking about coral reef conservation by focusing on coral reef restoration. The conventional wisdom was that creating protected areas, where reefs are sheltered from effluent, fishing, and other damaging human activities was the best strategy. In contrast, Williams was convinced that the restoration of coral reefs could play an important, and complementary, role.

Williams began by partnering with Frank Mars, Indonesian scientists from Hasanuddin University, graduate students from the University of California, Davis, and local Indonesian villagers to study whether reefs could be restored with "spiders" (large open-work frames) that could act as settlement surfaces for corals. Over the course of this multi-year project Williams faced three major setbacks that led her to reflect on her approaches, adapt when needed, and co-develop ways to move forward. The first major setback came with spider success: the restored corals attracted colorful reef fishes, which in turn attracted fishermen who used cyanide to stun and collect them for the lucrative aquarium trade. The cyanide also killed the coral, setting up conflict between the villagers who wanted to see the reefs restored and the fishermen who threatened this goal. The conflict became so heated that at one point the fisherman ripped out a section of rehab, piled the spiders above the water line, and stuck a white flag (signifying death) on top. The second setback came when Frank Mars wanted to abandon the project after learning about the cyanide fishing. And the last setback came from William's own self-doubt that stemmed from a lack of support from the academic community that favored marine protected areas (MPAs) over rehabilitation. 
Williams reflected on these challenges and probed her own efforts as she worked to develop cultural bridges among the diverse participants in this work, and disseminated the ideas back to other scientists with conference presentations and publications (Williams et al. 2019). Her self-awareness about these complex social interactions among her disparate partners were critical to the success of the work both in the coral reefs and in the scientific description of these novel experiments. And, the dissemination of her research results provided her with the evidence she needed to convince her colleagues and Mars to allow her to continue through these setbacks. In her own words "the collaboration and capacity building have contributed to my growth and satisfaction to a degree that my other projects never have." In the end, significant portions of the reef were restored and reef restoration is now a focus of multiple research and conservation efforts (Stewart-Sinclair et al. 2020, Vanderklift et al. 2020, Westoby et al. 2020).

\section{Empower: inspire and influence change}

To empower is to inspire action. Empowering includes training future generations; sharing lessons about leadership, process, and outcomes; providing a call to action for others; and convening ongoing conversations. The "Ethiopian Church Forest Conservation" project, overseen by Meg Lowman (TREE Foundation), is an example of how empowerment can lead to long-term local-actor solutions for preserving the forests of northern Ethiopia. The project started in 2008 to survey forest canopy biodiversity via aerial imagery in Ethiopian church forests. The researchers involved found these sanctuaries (preserved as "church forests" by the Coptic priests) were shrinking and losing their integrity at an alarming rate. The aerial images provided visual evidence and the priests' recollections confirmed this reality over a longer time frame. A partnership of religion and science emerged that focused on efforts to empower community leaders (the priests) and future leaders (the children).

To begin this initiative, Lowman and her local partner created workshops to educate church leaders about the value and ecological function of the trees surrounding their churches. The priests were well aware of their church forest losses and the value of these trees, but had no support from government or international experts to reverse or reduce the deforestation. They prayed, but had not undertaken any direct conservation actions. In these workshops, Google Earth images were used to illuminate these trees within a large sea of subsistence agriculture, providing the first clear visualization of the shrinking forests in each district. These workshops and the images empowered the priests to take on leadership roles with their parishes and work together with scientists toward conservation. At the priests' direction, and in conjunction with Lowman who raised funds to pay for the gates and transportation of stones, local communities are now building conservation walls around their church forests and creating a perimeter delineation to exclude grazing animals and protect the edge trees (Reynolds et al. 2017). The second empowerment came in the form of a children's book about the value of trees and including Ethiopian pictures and printing it in Amharic (Lowman and Mulat 2014, Lowman and Sinu 2017). ${ }^{[2]}$ The book includes lessons about the native biodiversity and highlights the importance of protecting and planting more church forests, empowering the next generation to continue with these efforts.

\section{BECOMING A COLLECTIVE LEADER}

Becoming a collective leader remains difficult because setting aside time for this type of training can be at odds with the traditional academic emphasis on scholarly research and the standards used for tenure and promotion. However, there is evidence that this traditional academic culture may be changing, and that non-academic partners are interested in this extended engagement (Jeanson et al. 2019). First, the change in focus of funding agencies (noted earlier) to require work with transdisciplinary groups suggests that funding incentives are becoming more in line with collective leadership (Jamieson 2020, Rose et al. 2020). Second, efforts by universities to change promotion and tenure processes (O'Meara et al. 2015, APLU 2019, NASEM 2020), reward engaged scholarship and publicimpact research (e.g., https://ptie.org/), teach science diplomacy (Gore et al. 2020), and engage in new faculty fellowship programs in public engagement (https://publicengagement.ucdavis.edu/ faculty-fellows-programs; https://ai.umich.edu/pe-faculty-fellowship/) suggest that collective leadership is becoming increasingly recognized in many academic settings.

We recommend researchers develop leadership skills by focusing on one or two of the dimensions and practicing those in an existing collaboration, while reflecting on whether adding this leadership framework could be useful in advancing other projects that involve putting knowledge into action. We suspect many researchers already use some or all of these dimensions, but may not have identified them as separate aspects of leadership. Based on our experience, naming the different dimensions and specifically examining how well each is being employed may advance both an individual's leadership skills and the collective group's progress. In other words, using the language of collective leadership can be an important first collaborative step that can help a team develop shared goals. Similarly, we recommend that leaders examine current collaborative efforts to put knowledge into action to see if there are places where the group is stuck or actions have stalled. Finally, additional insight into the examples above and four others can be found in the online resources and teaching tools provided on the Earth Leadership Program website (https://www.earthleadership.org/).

One common theme among our narratives was learning that these advances all required empathy and mutual respect. These case studies required long-term commitments that combined research and community knowledge to change attitudes, beliefs, individual and group behavior, or policy. However, the long-term commitments outlined here were important not in and of themselves, but because they helped researchers and others involved build the empathy required to move forward together when the setbacks and mistakes that inevitably occur do happen. To do this work, leaders must seek out team members from constituencies not traditionally considered, respect all members of the team, understand the different cultures involved, listen to what is being said, and understand that sometimes the scientist has credibility and sometimes they rightfully do not (Matson et al. 2016).

To help put these dimensions in practice, we detail how leaders can apply each collective leadership dimension in Table 2 and discuss counter-examples of what we identify as "non-collective" leadership practices (including transactional, transformational, 
Table 2. Practicing collective leadership.

\begin{tabular}{|c|c|c|}
\hline Dimension & Practices & Actions \\
\hline Inquire & $\begin{array}{l}\text { Have empathy: Balance voicing own views with other views. } \\
\text { Learn from other team members or sectors. Seek viewpoints } \\
\text { and knowledge from diverse perspectives. Respect different } \\
\text { types of knowledge. }\end{array}$ & $\begin{array}{l}\text { Ask questions; } \\
\text { Listen to hear, not to respond; } \\
\text { Convene interactive meetings. }\end{array}$ \\
\hline Connect & $\begin{array}{l}\text { Value and learn to collaborate: Maintain relationships by } \\
\text { checking in to exchange ideas. Build interdisciplinary and } \\
\text { cross-sector teams. Develop networks and build alliances } \\
\text { within and outside the academy. }\end{array}$ & $\begin{array}{l}\text { Maintain personal/team communication between face-to-face meeting } \\
\text { times; } \\
\text { Remain open to adding new approaches; } \\
\text { Continue to expand networks by building on other team member } \\
\text { networks. }\end{array}$ \\
\hline Engage & $\begin{array}{l}\text { Co-design, co-produce, co-implement: } \\
\text { Co-create a shared mission and vision for the project. }\end{array}$ & $\begin{array}{l}\text { Co-develop goals, expectations, and benchmarks; } \\
\text { Co-develop the team mission; } \\
\text { Co-create the team vision; } \\
\text { Co-design team roles. }\end{array}$ \\
\hline Strategize & $\begin{array}{l}\text { Be a systems thinker: Ensure that multiple dimensions of a } \\
\text { social environmental initiative are considered. Identify key } \\
\text { places in need of research or intervention and what outcomes } \\
\text { would signal success. }\end{array}$ & $\begin{array}{l}\text { Use project planning tools with collaborators to create deadlines; } \\
\text { Support and lead decision-making process conversations; } \\
\text { Co-develop a clear vision of a future state to define what success looks } \\
\text { like. }\end{array}$ \\
\hline Reflect & $\begin{array}{l}\text { Be intentional: Assess challenges and strengths by evaluating } \\
\text { personal strengths and team capabilities. }\end{array}$ & $\begin{array}{l}\text { Employ mechanisms to gather feedback and incorporate continuous } \\
\text { improvement; } \\
\text { Make certain actions are linked to values and strengths of the different } \\
\text { team members. }\end{array}$ \\
\hline Empower & $\begin{array}{l}\text { Integrate collective leadership: Model the practice through } \\
\text { one's teaching, mentoring, writing, and research. }\end{array}$ & $\begin{array}{l}\text { Practice participating in a non-traditional leadership role; } \\
\text { Mentor and teach the approach; } \\
\text { Allow others to lead. }\end{array}$ \\
\hline
\end{tabular}

and other categories of leadership) for comparison. This discussion is included to enable self-critical reflection that can help identify when leadership practices do and do not fit into the collective approach. Furthermore, these examples highlight when approaches different from collective leadership may be preferred. For example, in disaster or crisis response, less distributed leadership might be needed to develop an initial (and quick) response, and thus not practicing any of these dimensions in emergency situations may be appropriate. However, in situations where more top-down approaches are warranted (Chang and Trainor 2018), the objective to build trusted relationships, the hallmark of collective leadership, can be paramount to success (Smythe et al. 2016). Finally, note that while the case studies we have provided thus far outline how these dimensions can be applied in large projects, the dimensions can be applied in teaching, the oversight of undergraduate and graduate student projects, and in committee work.

We began with Inquiry, which requires balancing one's own views with active consideration of other views. Leaders who do not practice this dimension can be efficient and decisive decision makers, use their own views to drive the agenda, make unilateral decisions and prioritize efficiency over inclusivity. In cases where collective leadership is warranted, it can be valuable to include stakeholders with opposing viewpoints to strengthen the argument, identify potential flaws, and provide alternative views. Ensuring that opinions that are shared by a small number of people are heard, but do not dominate or disrupt the process, can be successful if ground rules and a mission are co-developed. Furthermore, including these stakeholders in the process is a constructive way to produce beneficial insights and productive conversations. In many transdisciplinary collaborations, the process itself is as much the product (e.g., West et al. 2019) as are any reports or outcomes. In those instances, the goal may be to establish a relationship from which future conversations can continue (such as diplomatic negotiations related to climate change or biodiversity in which participants may not share the same values or priorities).

The Connect dimension requires that leaders focus on relationships. Leaders who practice this dimension are interested in developing long-term relationships and maintaining these relationships by checking in to exchange ideas, building interdisciplinary and cross-sector teams, and building alliances within and outside the academy. Leaders who do not practice this dimension may focus instead on deadlines and tasks over relationships, and prioritize supporting and strengthening the current team and team members rather than expanding the team network.

The Engage dimension requires furthering the "co" aspects (codesigning, co-producing, and co-implementing) of the project. Leaders who do not practice this dimension may focus on personal achievement rather than group cohesion and progress, may fail to delegate many of the project tasks, and/or may unilaterally set team goals and expectations, pre-define the team mission, draft the initial team vision without input, and control the focus and responsibilities of team members.

The Strategize dimension requires that leaders identify key places in need of research or intervention and the outcomes that would signal success. For example, leaders who practice this approach may use project planning tools with collaborators to create deadlines, support and lead decision-making process conversations, and co-develop a clear vision of the future to define what success looks like. Leaders who do not practice this dimension may choose to set deadlines for the team, lead decisionmaking conversations, and self-define what success looks like. 
The Reflect dimension requires that a leader be intentional about gathering feedback and incorporating both failures and successes into future actions. For example, leaders who practice this dimension may employ mechanisms to gather feedback and incorporate continuous improvement and/or make certain actions are linked to values and strengths of the different team members. On the other hand, leaders who do not practice this dimension may focus on progress and moving forward and assign team member tasks according to field and/or previous roles instead of seeking to identify personal strengths that can evolve into new roles.

Last, the Empower dimension requires leaders to model the collective leadership practice through teaching, mentoring, writing, and research. Leaders who practice this dimension may practice participating in non-traditional leadership roles, mentor and teach the approach, and allow others to lead. Leaders who do not practice this dimension may focus on individual success, may not share power, and/or may maintain inflexible leadership roles.

\section{CONCLUSION}

Mobilizing knowledge to action and moving research findings outside of the ivory tower requires leadership. The challenge is that moving scientific findings from research labs to communities in need of this knowledge requires skills and roles beyond those fostered in traditional academic programs. The six leadership dimensions outlined in our Collective Leadership Model: Inquire, Connect, Engage, Strategize, Empower, and Reflect, provide a framework and common language for advancing these leadership skills and mobilizing knowledge for action. This framework encourages academic researchers to gather multiple perspectives, understand social and historical contexts, create shared goals, calculate solutions, assess strengths and weaknesses, and inspire ongoing action. Although applying these dimensions may appear to be a large undertaking, synergies noted in these narratives point to new empirical directions, research grants, and peer-reviewed publications, supporting the argument that moving to this framework has the potential to not only increase the broader impacts of research but also advance the outcomes that are already valued in academia.

\footnotetext{
${ }^{[1]}$ More than 200 fellows from over 80 universities and organizations have completed the program since it began in 1999. ${ }^{[2]}$ For every English copy of the book sold on Amazon.com, the publisher prints a copy in Amharic that is distributed free to the rural schools in Ethiopia.
}

Responses to this article can be read online at: https://www.ecologyandsociety.org/issues/responses. php/12396

\section{Acknowledgments:}

We are thankful to Jane Lubchenco, the founder and pioneer of the Leopold Leadership Program and to Pam Matson for mobilizing knowledge for action toward sustainability. The authors thank their many friends and collaborators who were involved in the work described in this paper: Dr. Alemayehu Wassie Eshete, champion of Ethiopian forest conservation; Professors Nadia al-Mudaffar Fawzi, Malik Hassan Ali, and Ali Douabul of the University of Basrah; and the investigators, students, and cooperators associated with the STRIPS project. Jill Caviglia-Harris was supported by National Socio-Environmental Synthesis Center (SESYNC) under funding received from the National Science Foundation DBI-1052875. Kathleen Galvin was supported by the USAID Climate Change Livestock Collaborative Research Support Program and by the International Social Science Council, Transformations to Sustainability Program (T2S_PP_066). Brian Helmuth was supported by the USAID Partnerships for Enhanced Engagement in Research (PEER) program. Lisa Schulte Moore was supported by the USDA-NIFA McIntire-Stennis Program. Dedication We dedicate this article to our friend, the late Susan Williams, director of the Bodega Marine Laboratory of the University of California, Davis; Leopold Leadership Fellow (2000); and renowned coral reef scientist.

\section{Data Availability:}

There are no data to make public.

\section{LITERATURE CITED}

Albarakat, R., V. Lakshmi, and C. J. Tucker. 2018. Using satellite remote sensing to study the impact of climate and anthropogenic changes in the Mesopotamian marshlands, Iraq. Remote Sensing 10(10):1524. https://doi.org/10.3390/rs10101524

Al-Mudaffar Fawzi, N., K. P. Goodwin, B. A. Mahdi, and M. L. Stevens. 2016. Effects of Mesopotamian Marsh (Iraq) desiccation on the cultural knowledge and livelihood of Marsh Arab women. Ecosystem Health and Sustainability 2(3):e01207. https://doi. org/10.1002/ehs 2.1207

Al-Mudaffar Fawzi, N., and B. A. Mahdi. 2014. Iraq's inland water quality and their impact on the north-western Arabian Gulf. Marsh Bulletin 9(1).

Ansell, C., and A. Gash. 2008. Collaborative governance in theory and practice. Journal of Public Administration Research and Theory 18(4):543-571. https://doi.org/10.1093/jopart/mum032

Arbuckle, J. G. 2019a. Iowa farm and rural life poll: 2018 summary report. Iowa State University Extension and Outreach, Ames, Iowa, USA.

Arbuckle, J. G. 2019b. STRIPS cooperator follow-on survey: 2018 results. Iowa State University Extension, Ames, Iowa, USA.

Association of Public and Land-Grant Universities (APLU). 2019. Public impact research: engaged universities making the difference. Report, APLU, Washington, D.C., USA.

Atwell, R. C., L. A. Schulte, and L. M. Westphal. 2009. Landscape, community, countryside: linking biophysical and social scales in U.S. corn belt agricultural landscapes. Landscape Ecology 24(6):791-806. https://doi.org/10.1007/s10980-009-9358-4

Baerwald, T. J., P. L. Firth, and S. L. Ruth. 2016. The dynamics of coupled natural and human systems program at the U.S. national science foundation: lessons learned in interdisciplinary 
funding program development and management. Current Opinion in Environmental Sustainability 19:123-133. https://doi. org/10.1016/j.cosust.2016.02.001

Bass, B. M. 1985. Leadership and performance beyond expectations. Free Press, New York, New York, USA.

Bass, B. M., B. J. Avolio, D. I. Jung, and Y. Berson. 2003. Predicting unit performance by assessing transformational and transactional leadership. Journal of Applied Psychology 88 (2):207-218. https://doi.org/10.1037/0021-9010.88.2.207

Bauer, M. W., N. Allum, and S. Miller. 2007. What can we learn from 25 years of PUS survey research? Liberating and expanding the agenda. Public Understanding of Science 16(1):79-95. https:// doi.org/10.1177/0963662506071287

Brigham, L. W. 2015. The GLACIER conference and President Obama's links to the Arctic. Arctic Yearbook. [online] URL: https://arcticyearbook.com/arctic-yearbook/2015/2015-commentaries/141the-glacier-conference-president-obama-s-links-to-the-arctic

Brownell, S. E., J. V. Price, and L. Steinman. 2013. Science communication to the general public: why we need to teach undergraduate and graduate students this skill as part of their formal scientific training. Journal of Undergraduate Neuroscience Education 12(1):E6-E10.

Bunzel, C. 2015. From paper state to caliphate: the ideology of the Islamic State. The Brookings Project on U.S. Relations with the Islamic World. The Brookings Institution, Washington, D.C., USA.

Cash, D. W., J. C. Borck, and A. G. Patt. 2006. Countering the loading-dock approach to linking science and decision making: comparative analysis of El Niño/Southern Oscillation (ENSO) forecasting systems. Science, Technology, \& Human Values 31 (4):465-494. https://doi.org/10.1177/0162243906287547

Cash, D. W., W. C. Clark, F. Alcock, N. M. Dickson, N. Eckley, D. H. Guston, J. Jäger, and R. B. Mitchell. 2003. Knowledge systems for sustainable development. Proceedings of the National Academy of Sciences 100(14):8086-8091. https://doi.org/10.1073/ pnas. 1231332100

Chang, R., and J. Trainor. 2018. Pre-disaster established trust and relationships: two major factors influencing the effectiveness of implementing the ICS. Journal of Homeland Security and Emergency Management 15(4):20170050. https://doi.org/10.1515/ jhsem-2017-0050

Clark, W. C. 2007. Sustainability science: a room of its own. Proceedings of the National Academy of Sciences 104 (6):1737-1738. https://doi.org/10.1073/pnas.0611291104

Clark, W. C., and A. G. Harley. 2020. Sustainability science: toward a synthesis. Annual Review of Environment and Resources 45(1):331-386. https://doi.org/10.1146/annurevenviron-012420-043621

Clark, W. C., L. van Kerkhoff, L. Lebel, and G. C. Gallopin. 2016. Crafting usable knowledge for sustainable development. Proceedings of the National Academy of Sciences 113 (17):4570-4578. https://doi.org/10.1073/pnas.1601266113
Cockburn, J., M. Rouget, R. Slotow, D. Roberts, R. Boon, E. Douwes, S. O'Donoghue, C. T. Downs, S. Mukherjee, W. Musakwa, O. Mutanga, T. Mwabvu, J. Odindi, A. Odindo, S. Mukherjee, W. Musakwa, O. Mutanga, T. Mwabvu, J. Odindi, A. Odindo, Ş. Procheş, S. Ramdhani, J. Ray-Mukherjee, Sershen, M. C. Schoeman, A. J. Smit, E. Wale, and S. Willows-Munro. 2016. How to build science-action partnerships for local land-use planning and management: lessons from Durban, South Africa. Ecology and Society 21(1):28. https://doi.org/10.5751/es-08109-210128

Denis, J. L., L. Lamothe, and A. Langley. 2001. The dynamics of collective leadership and strategic change in pluralistic organizations. Academy of Management Journal 44(4):809-837. https://doi.org/10.2307/3069417

Dennison, W. C., M. E. S. Bracken, M. Brown, J. F. Bruno, J. T. Carlton, R. C. Carpenter, T. J. B. Carruthers, M. N. Dethier, C. M. Duarte, T. R. Fisher, J. W. Fourqurean, R. K. Grosberg, L. J. Hamdan, K. L. Heck, D. J. Howard, A. R. Hughes, B. B. Hughes, G. A. Kendrick, W. J. Kenworthy, F. Mars, C. P. McRoy, R. L. Naylor, B. Nyden, J. C. Ogden, S. Olyarnik, R. J. Orth, F. T. Short, C. J. B. Sorte, J. J. Stachowicz, D. R. Strong, C. Sur, and M. Waycott. 2021. Susan Lynn Williams: the life of an exceptional scholar, leader, and friend (1951-2018). Estuaries and Coasts 44 (2):304-311. https://doi.org/10.1007/s12237-020-00886-y

Dilling, L., and M. C. Lemos. 2011. Creating usable science: opportunities and constraints for climate knowledge use and their implications for science policy. Global Environmental Change 21 (2):680-689. https://doi.org/10.1016/j.gloenvcha.2010.11.006

Dudo, A., and J. C. Besley. 2016. Scientists' prioritization of communication objectives for public engagement. PLoS ONE 11 (2):e0148867. https://doi.org/10.1371/journal.pone.0148867

Fazey, I., A. C. Evely, M. S. Reed, L. C. Stringer, J. Kruijsen, P. C. L. White, A. Newsham, L. Jin, M. Cortazzi, J. Phillipson, K. Blackstock, N. Entwistle, W. Sheate, F. Armstrong, C. Blackmore, J. Fazey, J. Ingram, J. Gregson, P. Lowe, S. Morton, and C. Trevitt. 2013. Knowledge exchange: a review and research agenda for environmental management. Environmental Conservation 40 (1):19-36. https://doi.org/10.1017/S037689291200029X

Fazey, I., N. Schäpke, G. Caniglia, A. Hodgson, I. Kendrick, C. Lyon, G. Page, J. Patterson, C. Riedy, T. Strasser, S. Verveen, D. Adams, B. Goldstein, M. Klaes, G. Leicester, A. Linyard, A. McCurdy, P. Ryan, B. Sharpe, G. Silvestri, A. Y. Abdurrahim, D. Abson, O. S. Adetunji, P. Aldunce, C. Alvarez-Pereira, J. M. Amparo, H. Amundsen, L. Anderson, L. Andersson, M. Asquith, K. Augenstein, J. Barrie, D. Bent, J. Bentz, A. Bergsten, C. Berzonsky, O. Bina, K. Blackstock, J. Boehnert, H. Bradbury, C. Brand, J. Böhme (born Sangmeister), M. M. Bøjer, E. Carmen, L. Charli-Joseph, S. Choudhury, S. Chunhachoti-ananta, J. Cockburn, J. Colvin, I. L. C. Connon, R. Cornforth, R. S. Cox, N. Cradock-Henry, L. Cramer, A. Cremaschi, H. Dannevig, C. T. Day, C. de Lima Hutchison, A. de Vrieze, V. Desai, J. Dolley, D. Duckett, R. A. Durrant, M. Egermann, E. Elsner (Adams), C. Fremantle, J. Fullwood-Thomas, D. Galafassi, J. Gobby, A. Golland, S. K. González-Padrón, I. Gram-Hanssen, J. Grandin, S. Grenni, J. Lauren Gunnell, F. Gusmao, M. Hamann, B. Harding, G. Harper, M. Hesselgren, D. Hestad, C. A. Heykoop, 
J. Holmén, K. Holstead, C. Hoolohan, A.-I. Horcea-Milcu, L. G. Horlings, S. M. Howden, R. A. Howell, S. I. Huque, M. L. Inturias Canedo, C. Y. Iro, C. D. Ives, B. John, R. Joshi, S. Juarez-Bourke, D. W. Juma, B. C. Karlsen, L. Kliem, A. Kläy, P. Kuenkel, I. Kunze, D. P. M. Lam, D. J. Lang, A. Larkin, A. Light, C. Luederitz, T. Luthe, C. Maguire, A.-M. Mahecha-Groot, J. Malcolm, F. Marshall, Y. Maru, C. McLachlan, P. Mmbando, S. Mohapatra, M.-L. Moore, A. Moriggi, M. Morley-Fletcher, S. Moser, K. M. Mueller, M. Mukute, S. Mühlemeier, L. O. Naess, M. Nieto-Romero, P. Novo, K. O'Brien, D. A. O'Connell, K. O’Donnell, P. Olsson, K. R. Pearson, L. Pereira, P. Petridis, D. Peukert, N. Phear, S. R. Pisters, M. Polsky, D. Pound, R. Preiser, Md. S. Rahman, M. S. Reed, P. Revell, I. Rodriguez, B. C. Rogers, J. Rohr, M. Nordbø Rosenberg, H. Ross, S. Russell, M. Ryan, P. Saha, K. Schleicher, F. Schneider, M. Scoville-Simonds, B. Searle, S. P. Sebhatu, E. Sesana, H. Silverman, C. Singh, E. Sterling, S.J. Stewart, J. D. Tàbara, D. Taylor, P. Thornton, T. M. Tribaldos, P. Tschakert, N. Uribe-Calvo, S. Waddell, S. Waddock, L. van der Merwe, B. van Mierlo, P. van Zwanenberg, S. J. Velarde, C.-L. Washbourne, K. Waylen, A. Weiser, I. Wight, S. Williams, M. Woods, R. Wolstenholme, N. Wright, S. Wunder, A. Wyllie, and H. R. Young. 2020. Transforming knowledge systems for life on Earth: visions of future systems and how to get there. Energy Research \& Social Science 70:101724. https://doi.org/10.1016/j. erss.2020.101724

Fischhoff, B. 2019. Evaluating science communication. Proceedings of the National Academy of Sciences 116 (16):7670-7675. https://doi.org/10.1073/pnas.1805863115

Fischhoff, B., and D. A. Scheufele. 2013. The science of science communication. Proceedings of the National Academy of Sciences 110(Supplement 3):14031-14032. https://doi.org/10.1073/ pnas. 1312080110

Fischhoff, B., and D. A. Scheufele. 2019. The science of science communication III. Proceedings of the National Academy of Sciences 116(16):7632-7633. https://doi.org/10.1073/pnas.1902256116

Flaherty, J. 2016. No more heroes: grassroots challenges to the savior mentality. AK Press, Chico, California, USA.

Francis, T. B., P. S. Levin, A. E. Punt, I. C. Kaplan, A. Varney, and K. Norman. 2018. Linking knowledge to action in ocean ecosystem management: the ocean modeling forum. Elementa: Science of the Anthropocene 6:83. https://doi.org/10.1525/ elementa. 338

Friedrich, T. L., J. A. Griffith, and M. D. Mumford. 2016. Collective leadership behaviors: evaluating the leader, team network, and problem situation characteristics that influence their use. Leadership Quarterly 27(2):312-333. https://doi. org/10.1016/j.leaqua.2016.02.004

Galvin, K. A., T. A. Beeton, R. B. Boone, and S. B. BurnSilver. 2015. Nutritional status of Maasai pastoralists under change. Human Ecology 43(3):411-424. https://doi.org/10.1007/s10745-015-9749$\underline{x}$

Galvin, K. A., T. L. Even, R. S. Reid, J. T. Njoka, J. R. de Pinho, P. K. Thornton, and K. Saylor. 2020. Understanding climate from the ground up: knowledge of environmental changes in the East African savannas. Pages 221-242 in M. Welch-Devine, A.
Sourdril, and B. J. Burke, editors. Changing climate, changing worlds: local knowledge and the challenges of social and ecological change. Springer International, Cham, Switzerland. https://doi.org/10.1007/978-3-030-37312-2_11

Galvin, K. A., R. S. Reid, M. E. Fernández-Giménez, D. ole Kaelo, B. Baival, and M. Krebs. 2016. Co-design of transformative research for rangeland sustainability. Current Opinion in Environmental Sustainability 20:8-14. https://doi. org/10.1016/j.cosust.2016.03.003

Généreux, M., M. Lafontaine, and A. Eykelbosh. 2019. From science to policy and practice: a critical assessment of knowledge management before, during, and after environmental public health disasters. International Journal of Environmental Research and Public Health 16(4):587. https://doi.org/10.3390/ ijerph16040587

Gerber, L. R., C. J. Barton, S. H. Cheng, and D. Anderson. 2020. Producing actionable science in conservation: best practices for organizations and individuals. Conservation Science and Practice 2(12):e295. https://doi.org/10.1111/csp2.295

Gordon, I. J., K. Bawa, G. Bammer, C. Boone, J. Dunne, D. Hart, J. Hellmann, A. Miller, M. New, J. Ometto, S. Pickett, G. Wendorf, A. Agrawal, P. Bertsch, C. D. Campbell, P. Dodd, A. Janetos, H. Mallee, and K. Taylor. 2019. Forging future organizational leaders for sustainability science. Nature Sustainability 2 (8):647-649. https://doi.org/10.1038/s41893-019-0357-4

Gore, M. L., E. S. Nichols, and K. R. Lips. 2020. Preparing scientists for science diplomacy requires new science policy bridges. Hague Journal of Diplomacy 15(3):424-434. https://doi. org/10.1163/1871191X-BJA10024

Gray, B. 2008. Enhancing transdisciplinary research through collaborative leadership. American Journal of Preventive Medicine 35(2):S124-S132. https://doi.org/10.1016/j.amepre.2008.03.037

Gumusluoglu, L., and A. Ilsev. 2009. Transformational leadership, creativity, and organizational innovation. Journal of Business Research 62(4):461-473. https://doi.org/10.1016/j. jbusres.2007.07.032

Guston, D. 2001. Boundary organizations in environmental policy and science: an introduction. Science, Technology, \& Human Values 26(4):399-408. https://doi.org/10.1177/016224390102600401

Haidt, J. 2012. The righteous mind: why good people are divided by politics and religion. Vintage, New York, New York, USA.

Hamstra, M. R. W., N. W. Van Yperen, B. Wisse, and K. Sassenberg. 2014. Transformational and transactional leadership and followers' achievement goals. Journal of Business and Psychology 29(3):413-425. https://doi.org/10.1007/s10869-013-9322-9

Hanson, T. 2018. Biodiversity conservation and armed conflict: a warfare ecology perspective. Annals of the New York Academy of Sciences 1429(1):50-65. https://doi.org/10.1111/nyas.13689

Hurlbert, M., and J. Gupta. 2015. The split ladder of participation: a diagnostic, strategic, and evaluation tool to assess when participation is necessary. Environmental Science \& Policy 50:100-113. https://doi.org/10.1016/j.envsci.2015.01.011 
Jamieson, K. H. 2020. Reconceptualizing public engagement by land-grant university scientists. Proceedings of the National Academy of Sciences 117(6):2734-2736. https://doi.org/10.1073/ pnas. 1922395117

Jeanson, A. L., P. Soroye, A. N. Kadykalo, T. D. Ward, E. Paquette, A. E. I. Abrams, D. A. Algera, D. Demers, L. J. Epp, M. P. Giles, M. A. Litt, B. A. Manouchehri, R. J. James, S. McBeth, A. Paradis, L. Pittet, J. Sebes, S. C. Steell, A. Thompson, P. Tremblay, E. I. Tuononen, J. T. Kerr, J. R. Bennett, and S. J. Cooke. 2019. Twenty actions for a "good Anthropocene"perspectives from early-career conservation professionals. Environmental Reviews 28(1):99-108. https://doi.org/10.1139/ er-2019-0021

Kapitulčinová, D., A. AtKisson, J. Perdue, and M. Will. 2018. Towards integrated sustainability in higher education - mapping the use of the Accelerator toolset in all dimensions of university practice. Journal of Cleaner Production 172:4367-4382. https:// doi.org/10.1016/j.jclepro.2017.05.050

Knapp, C. N., R. S. Reid, M. E. Fernández-Giménez, J. A. Klein, and K. A. Galvin. 2019. Placing transdisciplinarity in context: a review of approaches to connect scholars, society and action. Sustainability 11(18):4899. https://doi.org/10.3390/su11184899

Kristjanson, P., R. S. Reid, N. Dickson, W. C. Clark, D. Romney, R. Puskur, S. MacMillan, and D. Grace. 2009. Linking international agricultural research knowledge with action for sustainable development. Proceedings of the National Academy of Sciences 106(13):5047-5052. https://doi.org/10.1073/pnas.0807414106

Lauber, T. B., R. C. Stedman, D. J. Decker, and B. A. Knuth. 2011. Linking knowledge to action in collaborative conservation. Conservation Biology 25(6):1186-1194. https://doi.org/10.1111/ j.1523-1739.2011.01742.x

Logan, R. A. 2001. Science mass communication: its conceptual history. Science Communication 23(2):135-163. https://doi. org/10.1177/1075547001023002004

Lowman, M. D., and W. Mulat. 2014. Beza, who saved the forests of Ethiopia, one church at a time - a conservation story. Peppertree, Sarasota, Florida, USA.

Lowman, M. D., and P. A. Sinu. 2017. Can the spiritual values of forests inspire effective conservation? BioScience 67(8):688-690. https://doi.org/10.1093/biosci/bix057

Lubchenco, J. 1998. Entering the century of the environment: a new social contract for science. Science 279(5350):491-497. https://doi.org/10.1126/science.279.5350.491

Manolis, J. C., K. M. Chan, M. E. Finkelstein, S. Stephens, C. R. Nelson, J. B. Grant, and M. P. Dombeck. 2009. Leadership: a new frontier in conservation science. Conservation Biology 23 (4):879-886. https://doi.org/10.1111/j.1523-1739.2008.01150.x

Matson, P., W. C. Clark, and K. Andersson. 2016. Pursuing sustainability: a guide to the science and practice. Princeton University Press, Princeton, New Jersey, USA.

Mayer, A. 2020. Iowa State researchers' prairie strips now part of federal conservation program. Iowa Public Radio, 20 January. [online] URL: https://www.iowapublicradio.org/agriculture/2020-01-20/ iowa-state-researchers-prairie-strips-now-part-of-federal-conservationprogram

McAuliffe, E., A. De Brun, M. Ward, M. O'Shea, U. Cunningham, R. O’Donovan, S. McGinley, J. Fitzsimons, S. Corrigan, and N. McDonald. 2017. Collective leadership and safety cultures (Co-Lead): protocol for a mixed-methods pilot evaluation of the impact of a co-designed collective leadership intervention on team performance and safety culture in a hospital group in Ireland. BMJ Open 7(11):e017569. https://doi. org/10.1136/bmjopen-2017-017569

Mendez, M. J., J. P. Howell, and J. W. Bishop. 2015. Beyond the unidimensional collective leadership model. Leadership \& Organization Development Journal 36(6):675-696. https://doi. org/10.1108/LODJ-11-2013-0141

Miller, T. R. 2013. Constructing sustainability science: emerging perspectives and research trajectories. Sustainability Science 8 (2):279-293. https://doi.org/10.1007/s11625-012-0180-6

Miloy, J., and B. Crowder. 1983. Creating the college of the sea: the origin of the sea grant program. Texas A\&M University Sea Grant College Program, College Station, Texas, USA.

Mitchell, M. G. E., E. M. Bennett, A. Gonzalez, M. J. Lechowicz, J. M. Rhemtulla, J. A. Cardille, K. Vanderheyden, G. PoirierGhys, D. Renard, S. Delmotte, C. H. Albert, B. Rayfield, M. Dumitru, H.-H. Huang, M. Larouche, K. N. Liss, D. Y. Maguire, K. T. Martins, M. Terrado, C. Ziter, L. Taliana, and K. Dancose. 2015. The Montérégie Connection: linking landscapes, biodiversity, and ecosystem services to improve decision making. Ecology and Society 20(4):15. https://doi.org/10.5751/ES-07927-200415

Moser, S. 2016. Editorial overview: transformations and codesign: co-designing research projects on social transformations to sustainability. Current Opinion in Environmental Sustainability 20:v-viii. https://doi.org/10.1016/j.cosust.2016.10.001

Muñoz-Erickson, T. A., and B. B. Cutts. 2016. Structural dimensions of knowledge-action networks for sustainability. Current Opinion in Environmental Sustainability 18:56-64. https://doi.org/10.1016/j.cosust.2015.08.013

Naess, L. O. 2013. The role of local knowledge in adaptation to climate change. WIREs Climate Change 4(2):99-106. https://doi. org/10.1002/wcc.204

National Academies of Sciences, Engineering, and Medicine (NASEM). 2017. Accomplishments of the U.S. Global Change Research Program. National Academies Press, Washington, D. C., USA.

National Academies of Sciences, Engineering, and Medicine (NASEM). 2018. Graduate STEM education for the 21st century. National Academies Press, Washington, D.C., USA. https://doi. org/10.17226/25038

National Academies of Sciences, Engineering, and Medicine (NASEM). 2020. Re-envisioning promotion and advancement of STEM faculty. NASEM, Proceedings of a workshop-in brief. National Academies Press, Washington, D.C., USA. https://doi. org/10.17226/25742 
O’Meara, K., T. Eatman, and S. Petersen. 2015. Advancing engaged scholarship in promotion and tenure: a roadmap and call for reform. Association of American Colleges \& Universities: A Voice and a Force For Liberal Education, Washington, D.C., USA

Ostrom, E. 1996. Crossing the great divide: coproduction, synergy, and development. World Development 24(6):1073-1087. https://doi.org/10.1016/0305-750X(96)00023-X

Pohl, C., P. Krütli, and M. Stauffacher. 2017. Ten reflective steps for rendering research societally relevant. GAIA - Ecological Perspectives for Science and Society 26(1):43-51. https://doi. org/10.14512/gaia.26.1.10

Reynolds, T. W., C. D. Collins, A. Wassie, J. Liang, W. Briggs, M. Lowman, T. S. Sisay, and E. Adamu. 2017. Sacred natural sites as mensurative fragmentation experiments in long-inhabited multifunctional landscapes. Ecography 40(1):144-157. https:// doi.org/10.1111/ecog.02950

Richardson, C. J., P. Reiss, N. A. Hussain, A. J. Alwash, and D. J. Pool. 2005. The restoration potential of the Mesopotamian marshes of Iraq. Science 307:1307-1311. https://doi.org/10.1126/ science. 1105750

Rose, K. M., E. M. Markowitz, and D. Brossard. 2020. Scientists' incentives and attitudes toward public communication. Proceedings of the National Academy of Sciences 117 (3):1274-1276. https://doi.org/10.1073/pnas.1916740117

Safford, H. D., S. C. Sawyer, S. D. Kocher, J. K. Hiers, and M. Cross. 2017. Linking knowledge to action: the role of boundary spanners in translating ecology. Frontiers in Ecology and the Environment 15(10):560-568. https://doi.org/10.1002/fee.1731

Schulte, L. A., H. Asbjornsen, R. Atwell, C. Hart, M. Helmersl, T. Isenhart, R. Kolka, M. Liebman, J. Neal, M. O’Neal, R. Schultz, S. Secchi, J. Thompson, and M. Tomer. 2008. Targeted conservation approaches for improving water quality: multiple benefits for expanded opportunities. Iowa State University Extension, Ames, Iowa, USA.

Schulte, L. A., J. Niemi, M. J. Helmers, M. Liebman, J. G. Arbuckle, D. E. James, R. K. Kolka, M. E. O'Neal, M. D. Tomer, J. C. Tyndall, H. Asbjornsen, P. Drobney, J. Neal, G. V. Ryswyk, and C. Witte. 2017. Prairie strips improve biodiversity and the delivery of multiple ecosystem services from corn-soybean croplands. Proceedings of the National Academy of Sciences 114 (42):11247-11252. https://doi.org/10.1073/pnas.1620229114

Science-based Trials of Rowcrops Integrated with Prairie Strips (STRIPS). 2017a. A landowner's guide to prairie strips. STRIPS, Iowa State University Extension and Outreach, Ames, Iowa, USA.

Science-based Trials of Rowcrops Integrated with Prairie Strips (STRIPS). 2017b. Farming with prairie strips. STRIPS, Iowa State University Extension and Outreach, Ames, Iowa, USA.

Science-based Trials of Rowcrops Integrated with Prairie Strips (STRIPS). 2017c. Installing prairie strips: frequently asked questions. STRIPS, Iowa State University Extension and Outreach, Ames, Iowa, USA.
Science-based Trials of Rowcrops Integrated with Prairie Strips (STRIPS). 2017d. Prairie strips: small changes, big impacts. STRIPS, Iowa State University Extension and Outreach, Ames, Iowa, USA.

Science-based Trials of Rowcrops Integrated with Prairie Strips (STRIPS). 2017e. The cost of prairie strips. STRIPS, Iowa State University Extension and Outreach, Ames, Iowa, USA.

Senge, P., H. Hamilton, and J. Kania. 2015. The dawn of system leadership. Stanford Social Innovation Review Winter:27-33.

Smythe, T., N. Andrescavage, and C. Fox. 2016. The Rhode Island ocean special area management plan, 2008-2015: from inception through implementation. Pages 1-80 in J. McCann, editor. Case studies of marine spatial planning report series. Coastal Resources Center and Rhode Island Sea Grant College Program, URI Graduate School of Oceanography, Narragansett, Rhode Island, USA.

Stephens, J. C. 2020. Diversifying power: why we need antiracist, feminist leadership on climate and energy. Island, Washington, D.C., USA.

Stewart-Sinclair, P. J., J. Purandare, E. Bayraktarov, N. Waltham, S. Reeves, J. Statton, E. A. Sinclair, B. M. Brown, Z. I. Shribman, and C. E. Lovelock. 2020. Blue restoration-building confidence and overcoming barriers. Frontiers in Marine Science 7:541700. https://doi.org/10.3389/fmars.2020.541700

Teutonico, R., B. Raubenheimer, S. Burch, B. Glazer, J. Goodall, S. Gopalakrishnan, M. Grubbs, J. Haines, L. Harris, S. Perry, and B. Raubenheimer. 2020. Coastlines and people (CoPe) synthesis report. The Coastlines and People $(\mathrm{CoPe})$ Synthesis Report Team, University Corporation for Atmospheric Research (UCAR), Cooperative Programs for the Advancement of Earth System Science (CPAESS), Boulder, Colorado, USA.

Thesiger, W. 1964. The marsh Arabs. Illustrated edition. Penguin Classics, New York, New York, USA.

United Nations Environment Programme (UNEP). 2001. The Mesopotamian marshlands: demise of an ecosystem. Early Warning and Assessment Technical Report, Division of Early Warning and Assessment, UNEP, Nairobi, Kenya.

U.S. Congress. 2018. H.R.2 - Agriculture Improvement Act of 2018. U.S. Congress, Washington, D.C., USA.

U.S. Department of Agriculture Farm Service Agency (USDA FSA). 2019. Conservation reserve program: clean lakes, estuaries and rivers initiative. USDA FSA, Washington, D.C., USA.

Vanderklift, M. A., C. Doropoulos, D. Gorman, I. Leal, A. J. P. Minne, J. Statton, A. D. L. Steven, and T. Wernberg. 2020. Using propagules to restore coastal marine ecosystems. Frontiers in Marine Science 7:724. https://doi.org/10.3389/fmars.2020.00724

van Kerkhoff, L., and L. Lebel. 2006. Linking knowledge and action for sustainable development. Annual Review of Environment and Resources 31(1):445-477. https://doi. org/10.1146/annurev.energy.31.102405.170850

Ward, M. E., A. De Brun, D. Beirne, C. Conway, U. Cunningham, A. English, J. Fitzsimons, E. Furlong, Y. Kane, A. Kelly, S. 
McDonnell, S. McGinley, B. Monaghan, A. Myler, E. Nolan, R. O'Donovan, M. O'Shea, A. Shuhaiber, and E. McAuliffe. 2018. Using co-design to develop a collective leadership intervention for healthcare teams to improve safety culture. International Journal of Environmental Research and Public Health 15 (6):1182. https://doi.org/10.3390/ijerph15061182

West, S., L. van Kerkhoff, and H. Wagenaar. 2019. Beyond "linking knowledge and action": towards a practice-based approach to transdisciplinary sustainability interventions. Policy Studies 40(5):534-555. https://doi.org/10.1080/01442872.2019.1618810

Westoby, R., S. Becken, and A. P. Laria. 2020. Perspectives on the human dimensions of coral restoration. Regional Environmental Change 20:109. https://doi.org/10.1007/s10113-020-01694-7

Williams, S. L., C. Sur, N. Janetski, J. A. Hollarsmith, S. Rapi, L. Barron, S. J. Heatwole, A. M. Yusuf, S. Yusuf, J. Jompa, and F. Mars. 2019. Large-scale coral reef rehabilitation after blast fishing in Indonesia. Restoration Ecology 27(2):447-456. https://doi. org/10.1111/rec. 12866 